\title{
Opportunities and Challenges in Realizing Universal Access to Obstetric Ultrasound in Sub-Saharan Africa
}

\section{두(ㅇ)(우)}

\section{Authors}

Sikolia Z Wanyonyi1 ${ }^{1}$, Charles Muriuki Mariara², Sudhir Vinayak ${ }^{3}$, William Stones ${ }^{4}$

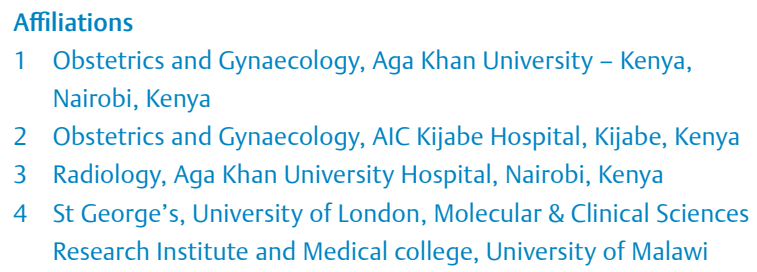

\author{
Correspondence \\ Dr. Sikolia Wanyonyi, MRCOG, MMED, MBChB \\ Obstetrics and Gynaecology \\ Aga Khan University - Kenya \\ 30270, Nairobi, 00100 \\ Kenya \\ Tel.: + 254/703/124 803 \\ sikolia.wanyonyi@aku.edu
}

\section{ABSTRACT}

The potential benefits of obstetric ultrasound have yet to be fully realized in sub-Saharan Africa (SSA), despite the region bearing the greatest burden of poor perinatal outcomes. We reviewed the literature for challenges and opportunities of universal access to obstetric ultrasound and explored what is needed to make such access an integral component of maternity care in order to address the massive burden of perinatal morbidity and mortality in SSA. Original peer-reviewed literature was searched in various electronic databases using a 'realist' approach. While the available data were inconclusive, they identify many opportunities for potential future research on the subject within the region that can help build a strong case to justify the provision of universal access to ultrasound as an integral component of comprehensive antenatal care.

\section{Introduction}

Obstetric ultrasound remains an integral component of prenatal care [1]. However, most women in sub-Saharan Africa (SSA) still go through pregnancy without the benefit of a single ultrasound examination [2,3]. The region is responsible for the majority of the global burden of perinatal morbidity and mortality and the inability to offer imaging in pregnancy is one of the vital service gaps that may need to be closed in order to end preventable stillbirths [4]. As the clinical value of sonography is well established, efforts now need to be geared towards making obstetric ultrasound part of comprehensive antenatal care. With current technological developments in equipment quality and increasing access to smaller devices and mobile data/telemetry links that enable provision of services in remote locations together with the phenomenal reduction in costs, it should be possible for sonography to be made available in all primary health care settings [5-7]. Indeed, we have deployed midwives trained to undertake antenatal scans using portable devices in settings remote from our hospital with image telemetry transmitted using cheap mobile phone technology with encouraging results (personal communications).

However, for any investment to be justifiable, the costs and benefits have to be considered. It is necessary to critically examine whether universal access to obstetric ultrasound in SSA will improve perinatal outcomes and also to consider the potential for harm and whether it will have a significant effect at all. The commonly appreciated benefits of access to obstetric ultrasound are well characterized $[2,8,9]$ but there is a dearth of authoritative guidance on its appropriate place in maternal health services in low resource settings in general and the SSA region in particular. Where guidance is available, it is very restrictive, limiting the extent of use and the potential benefits that can be derived from sonography [10]. While medically indicated ultrasound is safe [11], potential harm cannot be overlooked when advocating for universal access. Such harm could result from unstructured dissemination of randomly applied technology [12-16].

In this paper, we review some of the challenges and opportunities regarding access to obstetric ultrasound and explore what is needed to make such access an integral component of maternity care in order to address the massive burden of perinatal morbidity and mortality in sub-Saharan Africa.

\section{Methods}

We searched original peer-reviewed literature in various electronic databases including: MEDLINE, EMBASE, PUBMED, TRIP, Google Scholar, CINHAL (Nursing and Allied health). We restricted our 
search to papers written in English between the years 1990 to 2016. We searched for grey literature and also a reference list of relevant articles using the key words: Ultrasound and perinatal outcomes, obstetric ultrasound and maternal health. We further narrowed our search to specific aspects on perinatal outcomes: Birth injury, stillbirth, birth asphyxia, neonatal death, maternal satisfaction, training and technological advances. We included only original research done in the SSA region. Opinions, commentary and review articles were excluded. Owing to the paucity of primary research work on the topic, we adopted a 'realist' approach in our search and literature synthesis. This was done to ensure that we extracted as many relevant studies as possible on the subject that may provide necessary information that could guide policy as opposed to a formal systematic review that would otherwise exclude most of these studies, but taking due note of the limitations of interpretation that this approach might impose $[17,18]$. We referred to studies undertaken in well-resourced settings for comparative purposes.

\section{Results and Interpretation}

A total of 17 studies met the search criteria and were included in the review. A majority of the studies [14] were observational/descriptive studies with only 2 randomized control trials (RCTS) and 1 RCT protocol ( $\triangleright$ Table $\mathbf{1}$ ). These were broadly categorized into the following themes: ultrasound and perinatal outcomes, training, portable ultrasound and telemedicine and knowledge, perception and practice.

\section{Ultrasound and perinatal outcomes in SSA}

The role of obstetric ultrasound in improving perinatal outcomes was comprehensively addressed in the Routine Antenatal Diagnostic Imaging with Ultrasound (RADIUS) trial, which concluded that screening ultrasonography did not improve perinatal outcomes [19]. Interestingly, these findings have been supported by subsequent studies. In fact not only do they support the findings, but also show that ultrasonography could lead to an increase in obstetric interventions such as instrumental deliveries and cesarean section [20-22].

These findings of 'no evidence of benefit' are in contrast with the benefits of ultrasound to individual patients for determining gestational age, enabling early diagnosis of pregnancy problems, and the psychological benefits that have been separately described $[1,8,9]$. Clinicians in the SSA region are all too aware of how the lack of obstetric ultrasound results in 'unpleasant surprises' during labor or delivery. Some frequent encounters from our practice in SSA include unexpected twin gestation, undiagnosed placenta previa or morbidly adherent placenta resulting in unplanned hysterectomy and unanticipated massive obstetric hemorrhage. Other scenarios include undiagnosed breech presentation leading to unplanned difficult deliveries. In the event of additional undiagnosed congenital anomalies such as hydrocephalus, one has to resort to destructive procedures with resultant maternal trauma and morbidity and these are especially traumatic when undiagnosed until delivery, for example with a 'stuck head'. The frequency of these occurrences is unknown, mainly owing to a lack of reliable reporting systems. Our assumption is that these experiences are more common in regions in SSA with limited or no access to obstetric ul- trasound but the literature does not capture such episodes in a manner that is amenable to analysis. This contrast between formal findings of 'no evidence of benefit' and the type of every day clinical experiences described above lead us to question the clinical meaning of the findings from the previously quoted studies. If indeed ultrasound does not confer perinatal benefit, then one may want to assume that many countries have invested heavily in a technology that is non-essential. This is unlikely to be the case.

The potential benefits of wider access to obstetric ultrasound extend beyond considerations of perinatal mortality. In settings where the majority of pregnancies are 'low risk' and other service elements are fully deployed and effective, any additional interventions may not have a measurable impact on a major outcome such as mortality. Access to obstetric ultrasound could, however, have a wider range of effects. An important benefit has been demonstrated in some settings in SSA in the form of an increase in the number of women seeking antenatal care as a result of being offered ultrasound examinations [21-23] and this can be anticipated to translate to better maternal and perinatal outcomes. Studies have also proved the usefulness of ultrasound in targeted examinations [24]. Intrapartum-related adverse outcomes could be reduced by the adoption of simplified umbilical artery (UA) Doppler studies in late pregnancy in regions with high perinatal death rates $[25,26]$. Among the many ultrasound interventions, Doppler velocimetry of the UA and ductus venosus (DV) in fetal growth restriction with timely and appropriate interventions has been shown to significantly reduce stillbirth rates $[27,28]$.

\section{Avoiding adverse maternal outcomes}

One major role of ultrasound remains the accurate confirmation of gestational age. Accurate determination of gestational age has remained elusive in the SSA region. This has not only affected decision-making in pregnancy but also the interpretation of findings in perinatal research in the region. Accurate estimation of gestational age reduces the number of unnecessary interventions such as labor induction, iatrogenic preterm birth and primary cesarean section $[29,30]$. A major hindrance to accurate estimation of gestational age is late antenatal booking, for example with most women attending for the first time in the mid-second trimester. A range of community mobilization and health service approaches is needed to encourage women to attend earlier in pregnancy. However, access to ultrasonography for fetal biometry with the use of the femur length (FL)/head circumference $(\mathrm{HC})$ ratio in these settings has the potential for application in the 2 nd and early 3 rd trimester with almost equal accuracy [31].

Ultrasound could also play a major role in reducing adverse maternal outcomes, mainly "near miss" morbidity and mortality [32]. Emphasis has mainly been on the neonatal and fetal outcomes, yet maternal conditions directly contribute to the perinatal outcomes. For example, a study in Rwanda reported that up to $37 \%$ of patients could have a wrong diagnosis, which could be corrected by incorporating ultrasound in their care [33]. Ultrasound may also result in recognition of conditions that could otherwise have been missed and resulted in adverse outcomes such as a placenta previa, invasive placenta, undiagnosed multiple pregnancies and malpresentations, leading to life-saving interventions in up to $48 \%$ of women [32]. 
Table 1 Summary of studies.

\begin{tabular}{|c|c|c|c|c|c|}
\hline & Study design & Objective & Study size & Main findings & Country \\
\hline $\begin{array}{l}\text { Gonzaga MA et al. } \\
2009 \text { [35] }\end{array}$ & $\begin{array}{l}\text { Cross-sectional } \\
\text { qualitative }\end{array}$ & $\begin{array}{l}\text { To assess knowledge, } \\
\text { attitude and practice of } \\
\text { pregnant women } \\
\text { towards prenatal } \\
\text { sonography }\end{array}$ & $\begin{array}{l}30 \text { pregnant women } \\
\text { who had undergone } \\
\text { ultrasound }\end{array}$ & $\begin{array}{l}\text { Obstetric sonography is highly } \\
\text { appreciated as being vital for } \\
\text { antenatal care. However, there is } \\
\text { need for mothers and health care } \\
\text { providers to be well informed } \\
\text { about the safety and specific } \\
\text { purposes of obstetric sonography } \\
\text { and what it can and cannot } \\
\text { achieve. }\end{array}$ & Uganda \\
\hline $\begin{array}{l}\text { Goldenberg RL et al. } \\
2007 \text { [28] }\end{array}$ & $\begin{array}{l}\text { Secondary analysis } \\
\text { of demographic data }\end{array}$ & $\begin{array}{l}\text { To explore the relation- } \\
\text { ship between intrapar- } \\
\text { tum and antepartum } \\
\text { stillbirths and the various } \\
\text { measures of obstetric } \\
\text { care }\end{array}$ & $\mathrm{N} / \mathrm{A}$ & $\begin{array}{l}\text { The intrapartum stillbirth rate is } \\
\text { more closely related to various } \\
\text { measures of obstetric care, and is a } \\
\text { reasonably good reflection of the } \\
\text { quality of obstetric care in a } \\
\text { country. In developing countries, } \\
\text { the intrapartum stillbirth rate } \\
\text { correlates strongly with the } \\
\text { percentage of births by cesarean } \\
\text { section. }\end{array}$ & Multi-country \\
\hline $\begin{array}{l}\text { Meloni MF et al. } \\
2007[44]\end{array}$ & $\begin{array}{l}\text { Observational before } \\
\text { and after study }\end{array}$ & $\begin{array}{l}\text { To assess the feasibility of } \\
\text { a sonographic training } \\
\text { program and the effect } \\
\text { of the program on public } \\
\text { health care }\end{array}$ & 10 trainees & $\begin{array}{l}7 \text { of } 10 \text { trainees were admitted to } \\
\text { the second year of the sonographic } \\
\text { training program. The mean } \\
\text { monthly hospital earnings during } \\
\text { the } 3 \text {-course period were } 673200 \\
\text { Tanzanian shillings. }\end{array}$ & Tanzania \\
\hline $\begin{array}{l}\text { Greenwold N et al. } \\
2014 \text { [45] }\end{array}$ & $\begin{array}{l}\text { Prospective cohort } \\
\text { study }\end{array}$ & $\begin{array}{l}\text { To evaluate the feasibility } \\
\text { and sustainability of } \\
\text { basic obstetric } \\
\text { ultrasound training in } \\
\text { rural Africa }\end{array}$ & $\begin{array}{l}1744 \text { pregnant } \\
\text { women and medical } \\
\text { personnel }\end{array}$ & $\begin{array}{l}\text { The detection rates for the } \\
\text { different ultrasound variables were } \\
\text { similar in the } 2 \text { subgroups - except } \\
\text { for the detection of fetal } \\
\text { anomalies, which was significantly } \\
(P<0.001) \text { higher in the subgroup } \\
\text { scanned by trainees under the } \\
\text { supervision of the trainer. }\end{array}$ & Mozambique \\
\hline $\begin{array}{l}\text { Yeboah MY et al. } \\
2010 \text { [32] }\end{array}$ & $\begin{array}{l}\text { Cross-sectional } \\
\text { study }\end{array}$ & $\begin{array}{l}\text { To evaluate the } \\
\text { appropriateness of } \\
\text { requests for obstetric/ } \\
\text { gynecologic ultrasound }\end{array}$ & $\begin{array}{l}210 \text { women referred } \\
\text { for ultrasound }\end{array}$ & $\begin{array}{l}\text { The standardization of obstetric/ } \\
\text { gynecologic ultrasound request } \\
\text { forms may improve the clinical } \\
\text { information provided. Clinical } \\
\text { evaluation and provision of } \\
\text { sufficient clinical details should be } \\
\text { regarded as the gold standard of } \\
\text { practice. }\end{array}$ & Ghana \\
\hline $\begin{array}{l}\text { McClure EM et al. } \\
2014 \text { [8] }\end{array}$ & $\begin{array}{l}\text { Randomized control } \\
\text { trial }(R C T) \text { protocol }\end{array}$ & $\begin{array}{l}\text { To determine whether } \\
\text { ultrasound use will } \\
\text { improve care and } \\
\text { ultimately pregnancy } \\
\text { outcomes in low recourse } \\
\text { settings }\end{array}$ & $\begin{array}{l}58 \text { study clusters } \\
\text { each with a health } \\
\text { center and about } \\
500 \text { births per year }\end{array}$ & $\mathrm{N} / \mathrm{A}$ & Kenya \\
\hline $\begin{array}{l}\text { Geerts L et al. } 1996 \\
{[21]}\end{array}$ & RCT & $\begin{array}{l}\text { To assess the overall } \\
\text { adverse perinatal } \\
\text { outcome and use of ante- } \\
\text { natal and neonatal } \\
\text { services }\end{array}$ & $\begin{array}{l}988 \text { pregnant } \\
\text { women without risk } \\
\text { factors for } \\
\text { congenital } \\
\text { anomalies referred } \\
\text { for ultrasound } \\
\text { between } 18-24 \\
\text { weeks of gestation }\end{array}$ & $\begin{array}{l}\text { More suspected postdate } \\
\text { pregnancies occurred in control } \\
\text { patients, as well as more } \\
\text { amniocenteses for confirmation of } \\
\text { lung maturity. More babies of low } \\
\text { birth weight were born in the study } \\
\text { group. The incidence of overall or } \\
\text { major adverse perinatal outcome } \\
\text { was comparable. Routine } \\
\text { ultrasonography was accompanied } \\
\text { by a considerable increase in costs. }\end{array}$ & South Africa \\
\hline
\end{tabular}


- Table 1 Continued.

\begin{tabular}{|c|c|c|c|c|c|}
\hline & Study design & Objective & Study size & Main findings & Country \\
\hline $\begin{array}{l}\text { van Dyke B et al. } \\
2007 \text { [22] }\end{array}$ & Open cluster RCT & $\begin{array}{l}\text { Investigate the effect of } \\
\text { routine second } \\
\text { trimester ultrasound on } \\
\text { obstetric management } \\
\text { and pregnancy } \\
\text { outcomes }\end{array}$ & $\begin{array}{l}955 \text { women with } \\
\text { low-risk } \\
\text { pregnancies at } \\
18-23 \text { weeks of } \\
\text { gestation }\end{array}$ & $\begin{array}{l}\text { There were no significant } \\
\text { differences between the groups } \\
\text { in terms of prenatal hospitaliza- } \\
\text { tion, delivery, miscarriage, } \\
\text { perinatal mortality and low birth } \\
\text { weight rates. High priority can } \\
\text { therefore not be given to } \\
\text { provision of routine pregnancy } \\
\text { ultrasound screening in poorly } \\
\text { resourced settings. }\end{array}$ & South Africa \\
\hline $\begin{array}{l}\text { Tautz S et al. } 2000 \\
\text { [34] }\end{array}$ & Qualitative study & $\begin{array}{l}\text { To assess women's } \\
\text { experience of } \\
\text { ultrasound scanning } \\
\text { and how their } \\
\text { experience concurs } \\
\text { with health profession- } \\
\text { als' views }\end{array}$ & $\begin{array}{l}41 \text { pregnant } \\
\text { women and } \\
\text { observation of } 18 \\
\text { doctor-client } \\
\text { interactions }\end{array}$ & $\begin{array}{l}\text { Most women viewed ultrasound } \\
\text { as being beneficial. Some } \\
\text { expressed considerable fear. } \\
\text { Women overestimated the } \\
\text { diagnostic power of ultrasound. } \\
\text { Technology and its often } \\
\text { expatriate providers tend to be a } \\
\text { source of mystification and at the } \\
\text { same time non-technological } \\
\text { procedures provided by local staff } \\
\text { in the context of normal history } \\
\text { taking and antenatal care are } \\
\text { undervalued. Health staff } \\
\text { admitted, however, that since the } \\
\text { availability of ultrasound they } \\
\text { have been tempted to take } \\
\text { histories and physical examina- } \\
\text { tions less thoroughly than before. }\end{array}$ & Botswana \\
\hline $\begin{array}{l}\text { Oluoch AO et al. } \\
2015 \text { [36] }\end{array}$ & Descriptive study & $\begin{array}{l}\text { To describe the uptake } \\
\text { and provision of } \\
\text { antenatal care and } \\
\text { explore how pregnant } \\
\text { women and heath care } \\
\text { providers perceived the } \\
\text { provision of ultrasound } \\
\text { scanning }\end{array}$ & $\begin{array}{l}10 \text { nurses, } 59 \\
\text { pregnant women } \\
\text { and observation of } \\
357 \text { ANC } \\
\text { consultations }\end{array}$ & $\begin{array}{l}\text { Ultrasound scanning was } \\
\text { perceived to enhance antenatal } \\
\text { care by confirming pregnancy } \\
\text { status and enabling more } \\
\text { accurate estimation of gestation- } \\
\text { al age and the health status of } \\
\text { the fetus. }\end{array}$ & Kenya \\
\hline $\begin{array}{l}\text { Menshah et al. } \\
2014 \text { [37] }\end{array}$ & $\begin{array}{l}\text { Cross-sectional } \\
\text { study }\end{array}$ & $\begin{array}{l}\text { To determine } \\
\text { knowledge of antenatal } \\
\text { ultrasound, its use in } \\
\text { pregnancy, adequacy of } \\
\text { information provided } \\
\text { by health workers and } \\
\text { assessment of scanning } \\
\text { experience }\end{array}$ & $\begin{array}{l}337 \text { post-delivery } \\
\text { women }\end{array}$ & $\begin{array}{l}\text { Women perceived antenatal } \\
\text { ultrasound as a useful tool. There } \\
\text { is a lack of information flow from } \\
\text { health care providers to clients } \\
\text { concerning the indications for } \\
\text { ultrasound, the process involved } \\
\text { and the results of the procedure. }\end{array}$ & Ghana \\
\hline $\begin{array}{l}\text { Shah S et al. } 2015 \\
{[40]}\end{array}$ & Online survey & $\begin{array}{l}\text { To assess perceived } \\
\text { barriers to ultrasound } \\
\text { use in resource-limited } \\
\text { settings }\end{array}$ & $\begin{array}{l}138 \text { heath care } \\
\text { providers }\end{array}$ & $\begin{array}{l}\text { Lack of training is the primary } \\
\text { barrier to regular use of } \\
\text { ultrasound. }\end{array}$ & Multi-country \\
\hline $\begin{array}{l}\text { Bagayoko CO et al. } \\
2014 \text { [6] }\end{array}$ & $\begin{array}{l}\text { Cross-sectional } \\
\text { study }\end{array}$ & $\begin{array}{l}\text { To evaluate the impact } \\
\text { of telehealth on the } \\
\text { diagnosis and } \\
\text { management in } \\
\text { obstetrics and } \\
\text { cardiology, health care } \\
\text { costs from patients' } \\
\text { perspective and } \\
\text { attendance at health } \\
\text { centers in remote } \\
\text { areas. }\end{array}$ & 215 cases & $\begin{array}{l}\text { Telehealth removed health care } \\
\text { management systems in remote } \\
\text { areas. }\end{array}$ & Mali \\
\hline
\end{tabular}


- Table 1 Continued.

\begin{tabular}{|c|c|c|c|c|c|}
\hline & Study design & Objective & Study size & Main findings & Country \\
\hline $\begin{array}{l}\text { Swanson JO et al. } \\
2014 \text { [43] }\end{array}$ & $\begin{array}{l}\text { Prospective } \\
\text { observational } \\
\text { study }\end{array}$ & $\begin{array}{l}\text { To evaluate the } \\
\text { diagnostic impact of } \\
\text { limited obstetric } \\
\text { ultrasound in } \\
\text { identifying high-risk } \\
\text { pregnancies when used } \\
\text { as a screening tool }\end{array}$ & 939 patients & $\begin{array}{l}\text { Limited focused obstetric US } \\
\text { screening by midwives improved } \\
\text { the diagnosis of early pregnancy } \\
\text { complications as well as later } \\
\text { gestation twins and malpresenta- } \\
\text { tion. }\end{array}$ & Uganda \\
\hline $\begin{array}{l}\text { Wylie B] et al. } 2013 \\
\text { [42] }\end{array}$ & $\begin{array}{l}\text { Before and after } \\
\text { study }\end{array}$ & $\begin{array}{l}\text { To pilot the feasibility } \\
\text { and utility of adding } \\
\text { ultrasound to an } \\
\text { observational study for } \\
\text { the purpose of } \\
\text { gestational age } \\
\text { assessment }\end{array}$ & $\begin{array}{l}178 \text { pregnant } \\
\text { women }\end{array}$ & $\begin{array}{l}\text { Ultrasound should be used to } \\
\text { confirm gestational age and avoid } \\
\text { the misclassification of infants as } \\
\text { premature or growth restricted. }\end{array}$ & Malawi \\
\hline $\begin{array}{l}\text { Enakpene CA et al. } \\
2009[38]\end{array}$ & $\begin{array}{l}\text { Cross-sectional } \\
\text { study }\end{array}$ & $\begin{array}{l}\text { To determine the } \\
\text { reasons why pregnant } \\
\text { women desire a } \\
\text { prenatal ultrasound }\end{array}$ & $\begin{array}{l}222 \text { pregnant } \\
\text { women }\end{array}$ & $\begin{array}{l}\text { Preferences were influenced by } \\
\text { biosocial variables. }\end{array}$ & Nigeria \\
\hline $\begin{array}{l}\text { Shah SP et al. } 2009 \\
\text { [33] }\end{array}$ & $\begin{array}{l}\text { Before and after } \\
\text { study }\end{array}$ & $\begin{array}{l}\text { To investigate the } \\
\text { impact of a diagnostic } \\
\text { ultrasound program in } \\
2 \text { rural district hospitals }\end{array}$ & $\begin{array}{l}\text { Health care } \\
\text { providers in } 2 \text { rural } \\
\text { health facilities }\end{array}$ & $\begin{array}{l}\text { Ultrasound is a useful modality } \\
\text { that particularly benefits } \\
\text { women's health and obstetrical } \\
\text { care in the developing world. }\end{array}$ & Rwanda \\
\hline
\end{tabular}

\section{Knowledge, use and misuse of ultrasound}

Technological advances are usually received with lots of excitement among consumers. However, this could be detrimental to the achievement of the intended health benefits. Before any new technology is adopted, it is important that knowledge exists not only among those who will operate it but also the end users. In the case of obstetric ultrasound, it is important that health workers who intend to use it are trained on both the technical aspects and safety measures to achieve the desired results and minimize harm.

Knowledge among women in SSA on the usefulness of ultrasound is mixed. Even though some women may view ultrasound as beneficial others still express fear. Contextualizing the indication for use of obstetric ultrasound taking into consideration societal and cultural influences and appropriate communication could result in proper uptake and discourage inappropriate expectations and demand [34]. Health workers could play a key role in encouraging uptake by correct communication of the need for ultrasound and having the results communicated back not only to the referring practitioners but also directly to women at the point of care [35]. Used this way ultrasound may enhance antenatal care uptake as women get excited about the prospects of pregnancy confirmation, determination of the health status of their baby and confirmation of gestational age [36-38].

It is important to note that inappropriate indications for obstetric ultrasound and the amount of information that can be derived from the scan could result in inaccurate communication of results to patients. Standardization of obstetric ultrasound request cards to improve the detail of provided clinical information resulted in improved reporting [39]. There are also misconceptions of potential harm to the fetus and/or the mother and these could conse- quently affect uptake [35]. Lack of national policy and practice guidelines on appropriate use of ultrasonography in pregnancy in most low and middle-income countries (LMIC) has meant that service content and quality are not consistent.

Overuse of ultrasound especially for commercial gains is a real threat that cannot be ignored [12]. Many unnecessary scans could be performed when not indicated, mainly for financial gain. Moreover, the misuse of ultrasound for gender selection as evident in South and East Asia could result in anxiety regarding its adoption elsewhere $[15,16]$.

\section{Training in ultrasound}

Increase in knowledge and competencies in obstetric sonography can be achieved through appropriate training programs. One major challenge in LMICs is the lack of adequate human resources for health. Besides a lack of machines, health workers have identified training as the major barrier to ultrasound uptake in SSA [40]. One approach that has been adopted in some areas to address the shortage is 'task shifting' or 'task sharing'. Emerging evidence on the use of this approach has been reported. In Thailand, locally trained health workers in a refugee camp were able to obtain fetal biometry measurements that were associated with low standard deviation values and within the normal limits of published Asian and European populations [41]. Similar programs targeting mid-level health workers and midwives have proved successful. In one study, mid-level health care workers were able to significantly influence change in clinical care after being trained in sonography by identifying up to $87 \%$ of fetuses mislabeled as preterm and up to $27 \%$ of babies misclassified as small for gestational age [42]. Other strategies have included limited focused ultrasound training to enable 
its use as a triage tool in identifying high-risk pregnancies in need of specialized care. This approach led to improvement in recognition of twin gestation and accurate confirmation of gestational age [43]. In Rwanda, an ultrasound-training program showed a significant impact on patient clinical management especially with regards to the need for surgical interventions with a change in management plans of up to $43 \%$ [33].

\section{Sustaining obstetric ultrasound competencies among health care providers providing maternity care}

Most obstetric ultrasound training programs have been reported to be highly sustainable with adequate maintenance of acquired skills, long after the instructors leave $[12,33,44]$. However, there are still challenges with the content of training and how to sustain the acquired skills without tempting health workers to work beyond their levels of competence. Training programs should be aimed at addressing a specific service need and not to create experts in the field. One way to achieve this is to approach the training in a hierarchical manner. The initial step could involve identifying key persons in either obstetrics or radiology at regional/tertiary institutions to drive the process and provide leadership. Mechanisms of integrating obstetric and radiological services need to be harmonized. This senior leadership could then oversee the training of other cadres of health staff in obstetric scanning. The critical target group of providers should be midwives or other primary care-level personnel identified based on tailored task-shifted models appropriate to the population needs that avoid depleting other parts of the service. Such an approach may be sustainable and fruitful if done within a framework of supportive supervision with ready access to a referral chain.

The referral chain could consist of health workers with structured and certified levels of competencies. These can be stratified into basic, intermediate and advanced scanning competencies. The components of basic ultrasound would include: crown-rump length (CRL)/dating scans, confirmation of viability, identification of multiples, very gross anomalies, placenta previa and placental localization before repeat cesarean section. Intermediate competencies could include: fetal biometry, growth, amniotic fluid volume estimation and localization of fibroids or other adnexal masses. Advanced level competencies could consist of detailed anomaly assessment including cardiac assessment and multi-modal fetal assessment such as Doppler studies.

Good quality imaging and reporting can be obtained and maintained through team work by feeding specialist expertise into the broad health system while extending sub-specialist competencies and linking with other aspects of the 2 disciplines, including other imaging modalities in the case of radiology. In view of the very limited number of specialists and subspecialists in the field, the use of remote web-based training and updating of competencies could be adopted. This has been demonstrated to have similar levels of feasibility, efficiency and sustainability with the potential for improved outcomes relative to traditional training approaches [45]. There are also opportunities to exploit the use of telemetry to enhance and improve the interpretation of scans especially after the trainers are no longer present. Studies in Mali have demonstrated that, besides this technology improving diagnostic accuracy, it re- sults in a significant cost reduction and reduced referral to tertiary centers [6,7]. This approach is also associated with high rates of acceptability among health workers in Africa [39].

The potential for abuse of the knowledge gained for either monetary or personal gain via diversion of patients is, however, a consideration and there is a need for training and professional development to emphasize ethical principles of clinical practice and accountability to reduce misuse, overuse or misdiagnosis with ultrasound technology [45].

\section{The emerging role of portable ultrasound}

As with most technological advances, there is constant improvement and innovation, with smaller devices being developed that could still achieve the same purpose as older bulkier machines. These smaller devices have lower energy requirements and are easier to install and cheaper to maintain. This is a promising opportunity for increasing access to ultrasonography, especially in low resource settings where there are challenges with energy supply, security and space [46]. This could mitigate the high costs of installation and maintenance of equipment, which have been major barriers to ultrasound access in SSA [40]. Portable ultrasound units could also be useful at the point of care where there is a need to make an urgent decision in women who have not had a prior perinatal ultrasound. This could be used in the clinical situations described above that result in potentially lethal 'unpleasant surprises' [42, 43, 47]. Furthermore, inappropriate decisions made in an emergency setting can be made owing to a lack of access to ultrasound. This could be avoided with quick point-of-service ultrasounds. Examples include cases of women with fetal demise being rushed for cesarean delivery with the maternal pulsations being confused for fetal bradycardia.

Caution is still needed with the currently available portable technology as these devices may not yet have the capacity for more specialized examination and the image resolution may not be adequate to allow for the detection of subtle features [12]. There is no doubt that with time they will be refined to achieve the same results as current conventional machines. The suppliers or providers of these instruments should therefore consider improving the capabilities of these machines while reducing costs. They should also participate or even promote standardization in training to differentiate experts from routine users [3]. This will enable the application of newer technology with the potential to improve accessibility and quality of services. Overall, portable ultrasound holds great promise for the developing world $[47,48]$.

\section{Opportunities}

Obstetric ultrasound continues to be an integral part of quality obstetric care worldwide. This benefit could also be realized in low resource settings. The opportunity to test the benefit of obstetric ultrasound exists in these low resource settings. In these settings a large proportion of women do not yet have access to obstetric ultrasound. Therefore, meaningful randomized control trials can be conducted. Such a trial would be considered appropriate from an ethics standpoint firstly because these services do not currently exist; secondly since the service has been shown not to improve perinatal outcomes elsewhere so no harm will be done if some women are denied this opportunity; lastly the women who do not undergo the intervention will not have been denied any service 
since they will continue to receive the standard care they would have received anyway.

It is also becoming more difficult to justify restrictive approaches such as the ones advocated by the WHO antenatal models for LMIC in the light of experience from maternal health systems that have achieved very low rates of maternal and perinatal mortality. For instance, the WHO "focused antenatal care" model recommends the use of ultrasound only in special conditions such as twin or high order pregnancies and emphasizes that only examinations 'that serve an immediate purpose and that have been proven to be beneficial should be performed' [10]. This position is incomplete or even potentially misleading, since it is inevitably difficult to identify those women who may benefit from ultrasound without performing ultrasound in the first place. For example, it is not possible to know whether a woman has a multiple pregnancy and could potentially benefit from an ultrasound examination without an ultrasound being performed in the first place to determine the number of gestational sacs. Universal access to obstetric ultrasound should therefore be the default goal for service provision.

There are also opportunities to achieve gradual change regarding access to obstetric ultrasound emerging in the sub-Saharan African region (SSA), with the increasing specialist and generalist health workforce, a booming market for health services in some countries in the region, active healthcare professional bodies and increasing investment by national governments and transnational partners directed towards the achievement of the ambitious health improvement targets set out in the Sustainable Development Goals.

\section{Conclusion}

The potential benefits of obstetric ultrasound are yet to be fully realized in SSA due to challenges ranging from individual patients to institutional and national policies. While there may be conflicting evidence on the impact of universal access on perinatal outcomes, the region presents many research opportunities that could provide answers to these questions.

\section{Potential Research Areas}

There are several questions that have not yet been fully answered. These include:

1. The role of obstetric ultrasound in reducing composite perinatal outcomes (for example, including preterm birth, stillbirth and intrauterine growth restriction) in regions that do not yet have this technology available.

2. The role of ultrasound in avoiding adverse maternal outcomes and morbidities (near-miss events) and a means to assess the clinically important aspect of 'avoiding unpleasant surprises'.

3. The impact of the deployment of early pregnancy sonography on the uptake of antenatal care and the effects on women's pregnancy and birth preparedness.

4. How to scale up training and sustain competencies in obstetric ultrasound among health workers in low resource settings.

5. Improving communication skills among sonographers with emphasis on how to communicate ultrasound findings during and after scanning to women and to effectively use referral systems.
6. The potential role of portable ultrasound as a point of care tool in intrapartum decision-making.

7. The role of telemetry in improving both training and the interpretation of obstetric ultrasound.

\section{Conflict of interest}

The authors declare that they have no conflict of interest.

\section{References}

[1] FIGO Best practice in maternal-fetal medicine 2015. Ultrasound examination in pregnancy

[2] Ostensen H. Developing countries. Ultrasound Med Biol 2000; 26 (Suppl 1): s159-s161

[3] Sippel S, Muruganandan K, Levine A, Shah S. Review Article: Use of ultrasound in the developing world. Int J Emerg Med 2011; 4: 72

[4] de Bernis L, Kinney M, Stones W, ten Hoope-Bender P, Vivio D, Leisher S, Bhutta Z, Gülmezoglu M, Mathai M, Belizán J, Franco L, McDougall L, Zeitlin J, Malata A, Dickson K, Lawn J. Stillbirths: Ending preventable deaths by 2030. Lancet 2016; 387: 703-716

[5] Aliyu LD, Kurjak A, Wataganara T, Moreira de Sa RA, Pooh R, Sen C, Ebrashy A, Ara A, Stanojevic M. Ultrasound in Africa: What can really be done? J Prenat Med 2016; 44: 119-123

[6] Bagayoko CO, Traore D, Thevoz L, Diabate S, Pecoul D, Niang M, Bediang G, Traore ST, Anne A, Geissbuhler A. Medical and economic benefits of telehealth in low and middle-income countries: Results of a study in four district hospitals in Mali. BMC Health Serv Res 2014; 14 (Suppl 1): s9

[7] Bagayoko CO, Anne A, Fieschi M, Geissbuhler A. Can ICTs contribute to efficiency and provide equitable access to the health care system in sub-Saharan Africa? The Mali Experience. Yearb Med Inform 2011; 6: 33-38

[8] McClure EM, Nathan RO, Saleem S, Esamai F, Garces A, Chomba E, Tshefu A, Swanson D, Mabeya H, Figuero L, Mirza W, Muyodi D, Franklin H, Lokangaka A, Bidashimwa D, Pasha O, Mwenechanya M, Bose CL, Carlo WA, Hamidge KM, Leichty EA, Krebs N, Wallace DD, Swanson J, Koso-Thomas M, Widmer R, Goldenberg RL. First look: Cluster-randomised trial of ultrasound to improve pregnancy outcomes in low-income country settings. BMC Pregnancy Childbirth 2014; 14 (73): 2-8

[9] Salomon L], Alfirevic Z, Berghella V, Bilardo C, Hernandez-Andrade E, Johnsen SL, Kalache K, Leung KY, Malinger G, Munoz H, Prefumo F, Toi A, Lee W. ISUOG Clinical Standards Committee. Practice guidelines for performance of the routine mid-trimester fetal ultrasound scan. Ultrasound Obstet Gynecol 2010; 10: 1002

[10] World Health Organization. The WHO Antenatal Care Randomised Trial: Manual of the implementation of the new mode WHO/ RHR/0130. Geneva: WHO; 2010: p6

[11] Marinac-Dabic D, Krulewitch C], Moore RM. The safety of prenatal ultrasound exposure in human studies. Epidemiology 2002; 13: $\mathrm{s} 19-\mathrm{s} 22$

[12] Gammeltoft T, Thi H, Nguyen T. The commodification of obstetric ultrasound scanning in Hanoi, Viet Nam. Reprod Health Matters 2007; 15: $163-171$

[13] Greenhalgh S. Controlling births and bodies in village China. Am Ethnol 1994; 21: 3-30

[14] FIGO Safe Motherhood and Newborn Health Committee, ICM, White Ribbon Alliance, International Pediatric Association, WHO. Motherbaby friendly birthing facilities. Int J Gynecol Obstet 2015: 128: 95-99 
[15] Jha P, Kesler MA, Ram F, Ram U, Aleksandrowicz L, Bassani DG, Chandra S, Banthia JK. Trends in selective abortions of girls in India: Analysis of nationally representative birth histories from 1990 to 2005 and census data 1991 to 2011. Lancet 2011; 377: 1921-1928

[16] Junking C. Prenatal sex determination and sex-selective abortion in rural Central China. Popul Dev Rev 2001; 27: 259-281

[17] Pawson R, Greenhalgh T, Harvey G, Walshe K. "Realist review - a new method of systematic review designed for complex policy interventions". J Health Serv Res Policy 2005; 10 (supp 1): 21-34

[18] Wong G, Greenhalgh T, Westhorp G, Pawson R. "Realist methods in medical education research: What are they and what can they contribute?". Med Educ 2012; 46: 89-96

[19] Ewigman BG, Crane JP, Frogoletto FD, LeFevre ML, Bain RP, McNellis D.the RADIUS study group. Effect of prenatal ultrasound screening on perinatal outcome. N Engl J Med 1993; 329: 821-827

[20] Bricker L, Neilson JP, Dowswell T. Routine ultrasound in late pregnancy (after 24 weeks gestation). Cochrane Database of systematic Reviews 2015; 6: CD001451

[21] Geerts L, Brand E], Theron G. Routine obstetric ultrasound examinations in South Africa: Cost and effect on perinatal outcome-a prospective randomised controlled trial. Br J Obstet Gynaecol 1996; 103: 501-507

[22] Van Dyke B, Motto JA, Buchmann EJ. Routine second-trimester ultrasound for low risk pregnancies in a South African community. Int J Gynaecol Obstet 2007; 98: 257-258

[23] Hofmeyr G]. Routine ultrasound examination in early pregancy: Is it worthwhile in low-income countries? Ultrasound Obstet Gynecol 2009; 34: 367-370

[24] Carvalho JS, Mavrides E, Shinebourne EA, Campbell S, Thaliganathan B. Improving the effectiveness of routine prenatal screening for major congenital heart defects. Heart 2002; 88: 387-391

[25] Maggio L, Dahlke JD, Mendez-Figueroa H, Albright CM, Chauhan SP, Wenstrom KD. Perinatal outcomes with normal compared with elevated umbilical artery systolic-to-diastolic ratios in fetal growth restriction. Obstet Gynecol 2015; 125: 863-869

[26] Spinillo A, Montanari L, Bergante C, Gaia G, Chiara A, Fazzi E. Prognostic value of umbilical artery Doppler studies in unselected preterm deliveries. Obstet Gynecol 2005; 105: 613-620

[27] Haws RA, Yakoob MY, Soomro T, Menezes EV, Darmstadt GL, Bhutta ZA. Reducing stillbirths: Screening and monitoring during pregnancy and labour. BMC Pregnancy Childbirth 2009; 9 (Suppl 1): s5

[28] Goldenberg RL, McClure EM, Bann CM. The relationship of intrapartum and antepartum stillbirth rates to measures of obstetric care in developed and developing countries. Acta Obstet Gynecol 2007; 86: 1303-1309

[29] Robinson HP. A critical evaluation of sonar crown-rump length measurements. Br J Obstet Gynaecol 1975; 82: 702-710

[30] Bennett KA, Crane JMG, O'Shea P, Lacelle J, Hutchens D, Copel JA. First trimester ultrasound is effective in reducing postterm labor induction rates: A randomised controlled trial. Am J Obstet Gynecol 2004; 190: 1077-10781

[31] Papageorghiou AT, Kemp B, Stones W, Ohuma EO, Kennedy SH, Purwar M, Salomon LJ, Altman DG, Noble JA, Bertino E, Gravett MG, Pang R, Ismail LC, Barros FC, Lambert A, Jaffer YA, Victora CG, Bhutta ZA, Villar J. International Fetal Newborn Growth Consortium for the 21st Century (INTERGROWTH-21st). Ultrasound based gestational age estimation in late pregnancy. Ultrasound Obstet Gynecol 2016, doi:10.1002/uog.15894

[32] Okong P, Byamugisha J, Mirembe F, Byaruhanga R, Bergstrom S. Audit of severe maternal morbidity in Uganda-implications for quality of obstetric care. Acta Obstet Gynecol 2006; 85: 797-804
[33] Shah SP, Epino H, Bukhman G, Umulisa I, Dushimiyimana JMV, Reichman A, Noble VE. Impact of the introduction of ultrasound services in a limited resource setting: rural Rwanda 2008. BMC Int Health Hum Rights 2009; 9: 4

[34] Tautz S, Jahn A, Molokomme I, Gorgen R. Between fear and relief. How rural pregnant women experience foetal ultrasound in a Botswana district hospital. Soc Sci Med 2000; 59: 689-701

[35] Gonzaga MA, Kiguli-Malwadde E, Francis B, Rosemary B. Current knowledge, attitudes and practise of expectant women toward routine sonography in pregnancy at Naguru health centre, Uganda. Pan Afr Med J 2009; 8: 18

[36] Oluoch AO, Mwangome N, Kemp B, Seale AC, Koech A, Papageorghiou AT, Berkley JA, Kennedy SH. Jones COH. "You cannot know if it's a baby or not a baby": Uptake, provision and perceptions of antennal care and routine antenatal ultrasound scanning in rural Kenya. BMC Pregnancy Childbirth 2015; 15: 127

[37] Mensah YB, Nkyekyer K, Mensah K. The Ghanian woman's experience and perception of ultrasound use in antenatal care. Ghana Med J 2014; 48: $31-38$

[38] Enakpene CA, Morhason-Bello IO, Marinho AO, Adedokun BO, Kalejaiye AO, Sogo K, Gradamos SA, Awoyinka BS, Enabor OO. Clients' reasons for prenatal ultrasonography in Ibadan, South West of Nigeria. BMC Women's Health 2009; 9: 12

[39] Yeboah MY, Dassah ET, Odoi AT, Manu AA. The appropriateness of healthcare provider requests for obstetric and gynaecologic ultrasound in a low-resource setting. Int J Gynecol Obstet 2010; 111: 264-274

[40] Shah S, Bellows BA, Adedipe A, Totten JE, Backlund BH, Sajed D. Perceived barriers in the use of ultrasound in developing countries. Crit Ultrasound J 2015; 7: 11

[41] Rijken MJ, Mulder EJH, Papageorghiou AT, Thiptharakun S, Wah N, Paw TK, Dwell SLM et al. Quality of ultrasound biometry obtained by local health workers in a refugee camp on the Thai-Burmese border. Ultrasound Obstet Gynecol 2012; 40: 151-157

[42] Wylie B], Kalilani-Phiri L, Madanista M, Membe G, Nyirend O, Mawindo P, Kuyenda R, Malenga A, Masonbrink A, Makanani B, Thesing P, Laufer MK. Gestational age assessment in malaria pregnancy cohorts: $A$ prospective ultrasound demonstration project in Malawi. Malar J 2013; 12: 183

[43] Swanson JO, Kawooya MG, Swanson DL, Hippe DS, Dungu-Matovu P, Nathan R. The diagnostic impact of limited, screening obstetric ultrasound when performed by midwives in rural Uganda. J Perinatol 2014; 34: 508-512

[44] Meloni MF, Ferraioli G. Sonographic Training program at a District hospital in a developing country: Work in progress. Am J Roentgenol 2007; 189: W119-W122

[45] Greenwold N, Wallace S, Prost A. Jauniaux. Implementing and obstetric ultrasound training program in rural Africa. Int J Gynecol Obstet 2014; 124: 274-277

[46] LaGrone LN, Sadasivam V, Kushner AL, Groen RS. A review of training opportunities for ultrasonography in low and middle-income countries. Tropl Med Int Health 2012; 17: 808-819

[47] Harris RD, Marks WM. Compact ultrasound for improving maternal and perinatal care in low-resource settings: Review of the potential benefits, implementation challenges, and public health issues. J Ultrasound Med 2009; 28: 1067-1076

[48] Harvey HB, Ahn R, Price DD, Burke TF. Innovating for the developing world: Meeting the affordability challenge. Am J Roentgenol 2014; 203: $835-837$ 